\title{
12. INTERPRETATION OF MULTICHANNEL SEISMIC REFLECTION DATA, LEGS 56 AND 57, JAPAN TRENCH TRANSECT, DEEP SEA DRILLING PROJECT
}

\author{
Noriyuki Nasu, ${ }^{1}$ Roland von Huene, ${ }^{2}$ Yasufumi Ishiwada, ${ }^{3}$ Marcus Langseth,,${ }^{4}$ Terry Bruns, ${ }^{2}$ and Eiichi Honza ${ }^{5}$
}

\section{INTRODUCTION}

Studies of convergent margin tectonics along the Japan Trench Transect are based on geophysical as well as on drill and conventional sampling data. The large number of geophysical and geological studies in the 1960's made this area an attractive target for convergent margin drill core sampling. Once the transect was scheduled for drilling by the Glomar Challenger, the earth science community in Japan intensified its efforts to collect geophysical and geological data within the transect area. Many of these data are published in Japanese and international journals. This chapter describes both the seismic reflection records along which Legs 56 and 57 drilling took place and the reflection records made after drilling. The seismic data are interpreted in light of the drilling results.

\section{PREVIOUS STUDIES}

The Japanese Deep Sea Expeditions in 1959 marked the beginning of systematic continuous echo sounding in the area off northern Honshu. The flat topographic area 2000 to 3000 meters deep just west of Japan Trench axis was first defined in the results reported by Nasu and others (1960) and Nasu and Sato (1962). Nasu named that area the "Japanese Pacific Sea-Shelf" (Nasu, 1961a, 1961b, 1964). These flat areas are now commonly called the "deep sea terrace," under which the subsided Oyashio ancient landmass was discovered by Glomar Challenger's drilling at Site 439.

Since these expeditions across the Japan Trench, numerous geological and geophysical investigations have been carried out. The origin of the deep sea terrace was discussed by a number of authors (Nasu, 1961b, 1964; Iijima and Kagami, 1961; Sato, 1973; Hoshino et al., 1970; Murauchi et al., 1978). Topographic features of the Japan Trench were revealed from these and subsequent surveys (Iwabuchi, 1968; Iwabuchi and Mogi, 1973; Mogi, 1977; Honza, 1976, 1977). The location and thickness of sediment in basins around Japan were summarized by Ishiwada and Ogawa (1976). Gravity anomalies in the vicinity of Japan have been compiled by Tomoda (1973). The geophysical features of northwest Pacific trench margins were summarized by Uyeda (1974).

\footnotetext{
I Ocean Research Institute, University of Tokyo, Tokyo, Japan.

${ }^{2}$ U.S. Geological Survey, Menlo Park, California.

3 Japan National Oil Corp., Tokyo, Japan.

${ }^{4}$ Lamont-Doherty Geological Observatory, Palisades, New York.

${ }^{5}$ Geological Survey of Japan, Tsukuba, Japan.
}

One of the first major geophysical studies of the Japan Trench area off Sanriku in northern Honshu was the result of a joint U.S.-Japanese two-ship expedition and was reported by Ludwig and others (1966). They demonstrated that the trench seaward slope is broken by numerous normal faults presumed to have formed as a result of bending of the ocean crust into the trench. On the landward side of the trench, crust with a continental velocity structure was traced seaward to within $70 \mathrm{~km}$ of the Japan Trench axis. The intervening area along the lower part of the trench landward slope is composed of low-velocity $(2.5-3.0 \mathrm{~km} / \mathrm{s})$ sediment above material with ocean crust velocities $(4.7-5.0 \mathrm{~km} / \mathrm{s})$. The twoship refraction data reported by Ludwig and others are verified and extended by ocean bottom seismograph (OBS) refraction data (Yoshii and Asano, 1972; Nagumo, this volume) and sonobuoy refraction data (Murauchi et al., 1978, 1979). These studies are summarized in this volume (Murauchi and Ludwig). In the summary Murauchi and Ludwig show that crust with a continental velocity structure extends to within $30 \mathrm{~km}$ of the trench axis, and then changes in structure so that thick, low-velocity sediment rests on the second oceanic layer; typical ocean crust occurs seaward of the trench.

Seismic reflection surveys by the Ocean Research Institute of the University of Tokyo (ORI) between 1967 and 1976 are summarized by Honza and others (1977). In 1977 an additional presite survey was made by ORI including single-channel seismic reflection techniques, dredging, and coring (Nasu and Kobayashi, 1980). The regional tectonic pattern is uplift of the land and coastal side of the margin and depression of the seaward side. Superimposed on this regional tectonic pattern is a tectonic fabric of local uplift and subsidence. Broad folds that trend subparallel to the coastline are 20 to $50 \mathrm{~km}$ across and generally less than $50 \mathrm{~km}$ long. A geologic compilation from single-channel airgun records was also reported during this period by the Hydrographic Office of Japan (Sakurai et al., 1975). A subsequent single-channel seismic reflection, gravity, and magnetic survey in 1976 by the Geological Survey of Japan resulted in comprehensive geologic and geophysical maps that include the area off Sanriku, where the transect is located (Honza et al., 1977, 1978). The interpretive geologic sections by Honza and others (1978) of the area off Sanriku indicate a regional unconformity.

The first multichannel seismic reflection record showing deep structure in the Japan Trench transect was presented by Ishiwada and Ogawa (1976) and by Beck and others (1976) at the 9th World Petroleum Congress; copies were made available for IPOD use. This record 
clearly shows that a major angular unconformity extends across the seaward part of the continent to the middle of the trench slope. Other information about the unconformity was revealed in two holes that were drilled about $80 \mathrm{~km}$ landward of the west end of the JNOC seismic lines, in a joint venture by Teikoku and Gulf Oil Companies. ${ }^{6}$ Drill Hole Hachinohe $1 \mathrm{x}$ at $40^{\circ} 36^{\prime} 10^{\prime \prime} \mathrm{N}$ and $141^{\circ} 53^{\prime} 11^{\prime \prime} \mathrm{E}$, or $26 \mathrm{~km}$ offshore at the latitude of seismic record JNOC-1, was drilled to 3501 meters below sea level. The Neogene is thin or missing; the Paleogene is nearshore or paralic facies and is separated from the upper Cretaceous marine rock by an unconformity. Another unconformity separates the Upper and Lower Cretaceous rock, the latter reported as being like the Rikuchu Formation.

Drill Hole Kuji $1 \mathrm{x}$ at $40^{\circ} 03^{\prime} 25^{\prime \prime} \mathrm{N}$ and $142^{\circ} 06^{\prime} 37^{\prime \prime} \mathrm{E}$, or about $17 \mathrm{~km}$ offshore between JNOC seismic Records 1 and 2, was drilled to 3030 meters below sea level. The Neogene is underlain by Oligocene sedimentary rock of a paralic facies and is separated by an unconformity from Upper Cretaceous mudstone and sandstone. Another unconformity is reported between Cretaceous and possible Jurassic limestone that looks like the Torinosu limestone.

In seismic records landward-dipping beds below the unconformity are truncated, and beds above the unconformity locally lap down against it. The top of igneous ocean crust can be traced from the ocean basin beneath most of the trench landward slope, and the landward end of ocean crust underlies the seaward end of the unconformity. In the latter part of 1976 , two additional multichannel seismic reflection records across the proposed drilling transect were acquired by the Japan Petroleum Exploration Company (JAPEX), under contract to the Technology Research Center, Japan National Oil Corporation (JNOC). These records were intended primarily for oil and gas exploration and were generously offered to the IPOD program for selection of drill sites. Portions of the records have been published in the Japanese literature; they form the basis for sketches in the preliminary reports of Legs 56 and 57 (Langseth, Okada, et al., 1978; von Huene, Nasu, et al., 1978). They are published in their entirety for the first time in this volume. The magnetic anomaly field off northern Honshu was summarized from a survey with ships' tracks at $4 \mathrm{~km}$ (Oshimi et al., 1975), and an aeromagnetic map over part of the area was published two years later (Ogawa and Suyama, 1976). These maps show a north-trending sequence of low-amplitude circular highs. (See foldouts, back pocket, this volume, Part 1). In 1978, following drilling, JAPEX acquired for ORI two more multichannel records across the trench between the JNOC records (Nasu et al., 1979). The JNOC and ORI records contain clear indication of the regional unconformity and also illustrate truncation of the trench lower slope section, lack of ponded trench fill, and steep faults on the trench seaward slope.

\footnotetext{
${ }^{6}$ These data were kindly provided in March 1980 by Dr. Jinichi Aiba of Teiseki Tairikudana Kaihatsu Company.
}

Preliminary shipboard studies of Legs 56 and 57 drilling results indicated that the unconformity exhibited in the record of Beck et al. (1976) and still more clearly in the JNOC and ORI multichannel seismic records was created by subaerial erosion of an ancient land area, the Oyashio landmass (von Huene et al., 1978), which has now subsided 2 to $3 \mathrm{~km}$ at Sites 438 and 439. Hemipelagic slope deposits were recovered from all drill sites on the trench slope. Deposits tectonically accreted during subduction are inferred from seismic data to exist beneath the unsampled trench lower slope. These results are consistent with seismic refraction and single-channel seismic reflection studies. In summary, both pre- and postdrilling studies indicate that (1) crust with a continental velocity structure extends to the trench midslope and that in the Neogene it subsided from above sea level to bathyal depth; (2) the oceanic crust is normally faulted as it bends to form the trench seaward slope; and (3) the intervening zone consists of landwardtilted and poorly consolidated sediments beneath an apron of slope deposits.

\section{DESCRIPTION OF SEISMIC RECORDS}

Three seismic records were acquired by JNOC for the IPOD Japan Trench Transect-two on east-west tracks across the continental margin (JNOC Records 1 and 2) and one connecting the east-west records along a northsouth track (JNOC Record A, Figure 1). Although only the east-west records are presented here, the northsouth record was used to trace horizons of known age from Sites 438 and 439 on JNOC Record 1 to JNOC Record 2. Records 3 and 4 were acquired by ORI, but no seismic data connection with the JNOC records has yet been made. The data were collected during the winters of 1976 and 1977 and during 1978, with the JAPEX Kaiyomaru, using a DSF V digital acquisition system and a 16-gun array of 24.42-liter (1490-cu. in.) displacement. Data were recorded with a sample interval of $4 \mathrm{~ms}$ from 48 channels at 50 -meter group spacings; shots were at 50 -meter intervals. This record was processed to give a 24 -fold stack at 25 -meter intervals. The data-processing sequence used by JAPEX consisted of record edit, common depth point (CDP) gather and velocity analysis, gain recovery, deconvolution, normal moveout (NMO) correction and stacking, post-NMO deconvolution, filter, and print automatic gain control (AGC). The records so processed (back pocket, this volume, Pt. 1) were printed at a vertical exaggeration of $2: 1$ at the ocean floor.

The records are presented in three forms, progressing from seismic records to interpreted sections: (1) processed seismic records with time as the vertical axis (back pocket), (2) tracings of selected reflections (Figure 2 ), and (3) conversion of tracings to depth sketches (Figure 3). The original processed records contain numerous diffractions and multiples. The tracings are of selected reflections, eliminating multiples and diffractions, and show interpretation of major faults (Figure 2). These tracings were converted from time sections to sketched depth sections, using averaged velocities from various sources (Figure 4). 


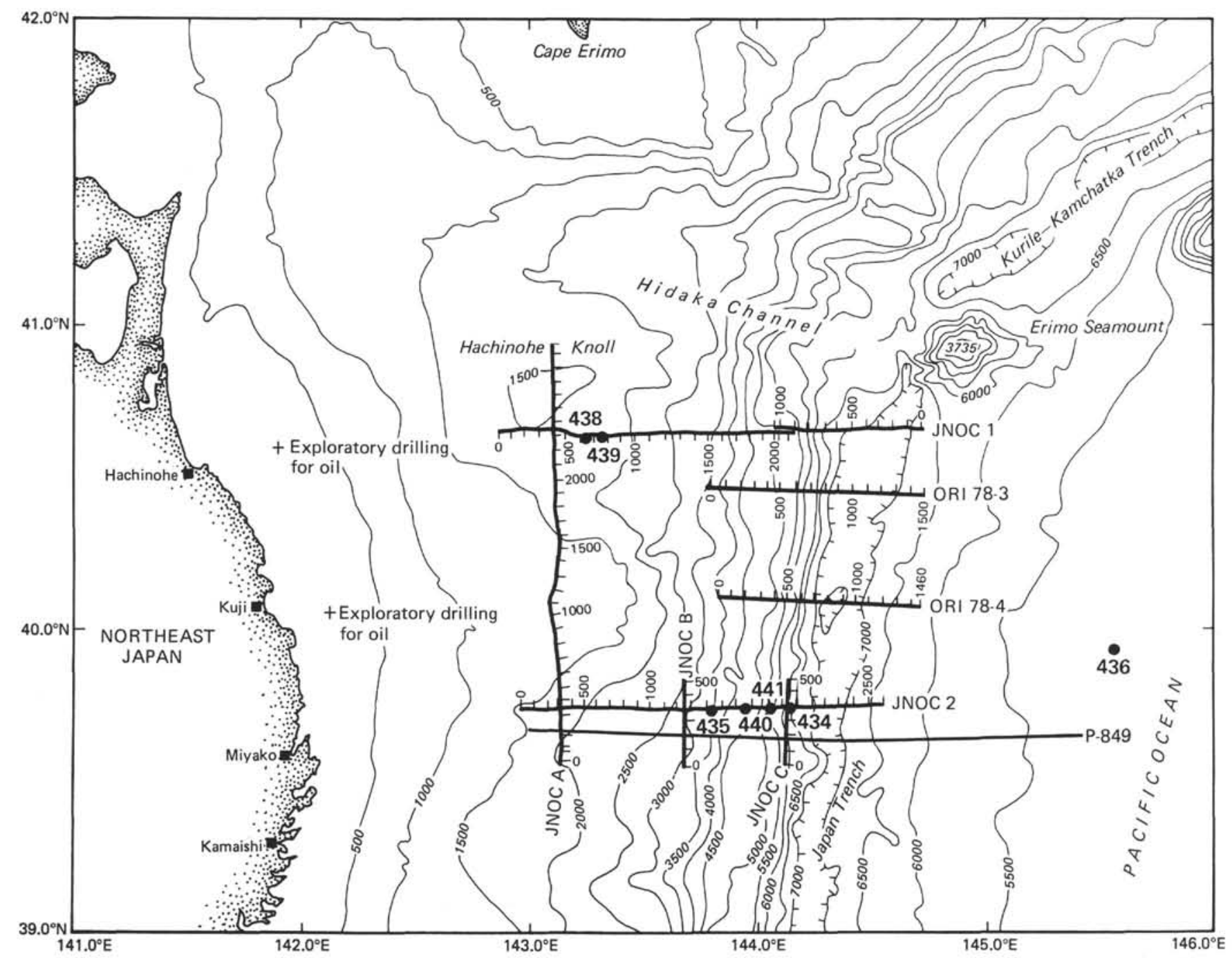

Figure 1. Map of northeastern Japan in the area of the Japan Trench Transect, showing the location of multichannel seismic reflection records and DSDP drill sites. (Records 1, 2, and A were acquired by JNOC; Records 3 and 4 were acquired by ORI [Nasu and others, 1979]; Record P-894 was acquired by Shell International Petroleum Co. [Beck and others, 1976]. A single-channel record from Nasu and Kobayashi [1980] was used to locate Site 436.)

Seismic velocities were measured in four ways along the Japan Trench transect. Velocities derived from seismic data include those from refraction measurements (Murauchi and Ludwig, Nagumo, both this volume) and from stacking velocities obtained during processing of the multichannel reflection. Velocities derived from downhole data include those from logging (Saki et al., this volume) and from laboratory measurements on cores (Carson and Bruns, this volume). Each of these measurements is averaged over a different volume of rock, and the agreement between the resulting velocities is a function of the homogeneity of the sediment section. The measurements on cores were made on small, coherent pieces at the shipboard laboratory temperature and pressure. The logging tool made in situ measurements in a small rock volume around the hole-in this case, under less favorable conditions than desired (Saki et al., this volume). The CDP reflection measurements average the seismic returns from a path that is up to a few kilometers long, and the refraction measurements average the travel time over an even longer path. Nonetheless, the measurements correspond well for the hemipelagic slope section near Sites 438 and 439 . The rapid increase in the velocity below one-second two-way travel time measured by downhole logging at Site 439 results from increasing sand content in turbidites deposited proximal to the subsiding Oyashio ancient landmass. A shallower velocity increase in logs from Site 440 is unexplained (Figure 4 and Saki et al., this volume).

The difference between velocities measured with seismic techniques and those obtained from logging and laboratory measurements indicates the uncertainty in velocity data and the resulting depth conversion. At 900 meters depth, the averaged seismic and log curves give depths differing by about 30 meters. Below 900 meters, where logging was not possible, the depth differences are greater and imprecisions additive with depth.

The configuration of the sea floor seen in the seismic records is similar to that of a continental shelf and slope. Because the shelflike area is deeper than $1 \mathrm{~km}$ it 

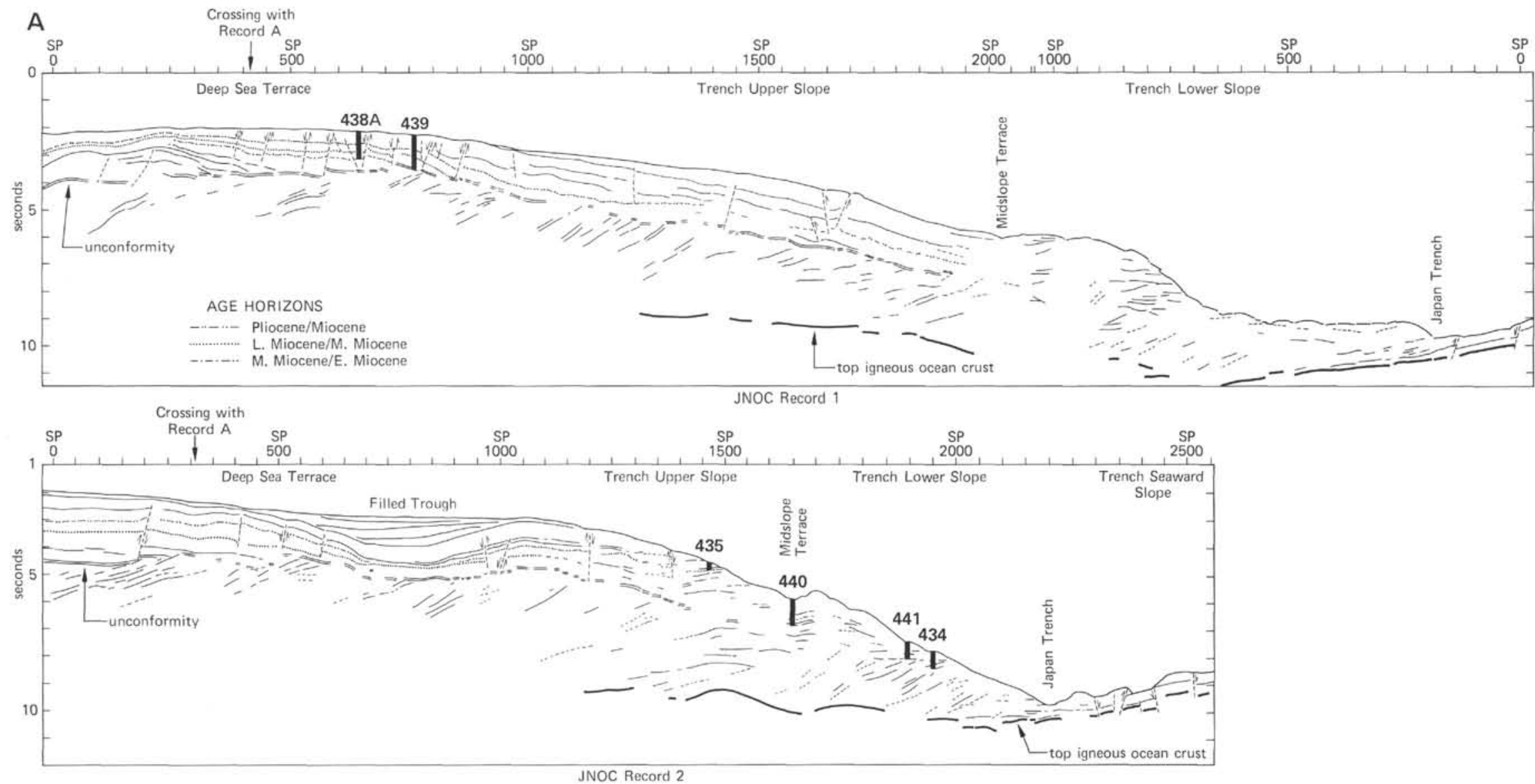


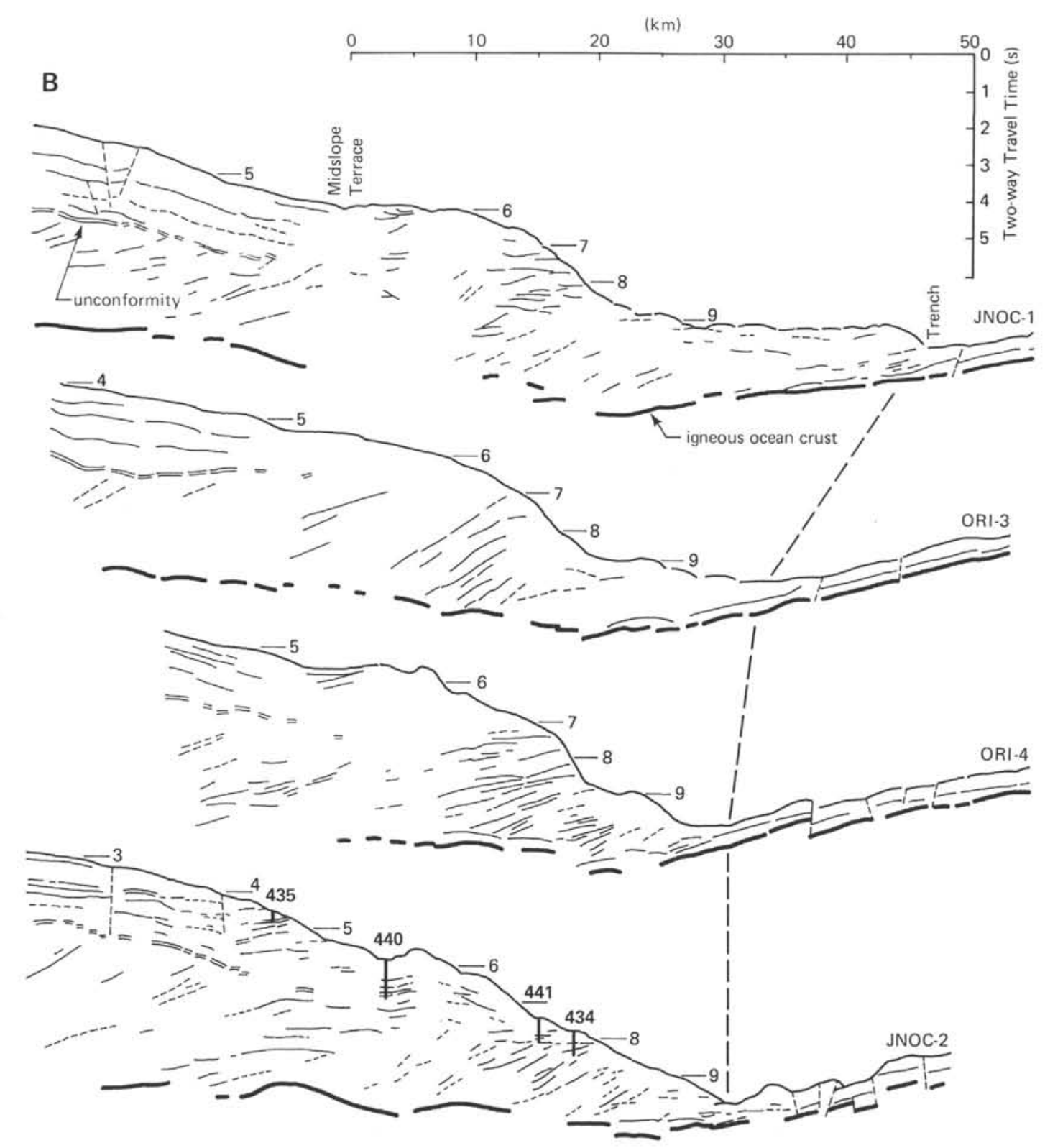

Figure 2. Tracings of selected reflections in multichannel seismic reflection records and interpretations of faults. DSDP drill sites are shown by site numbers above JNOC Records 1 and 2. (Age boundaries are dashed where there is a loss of reflection continuity; dash tracings of reflections indicate weak amplitude and perhaps a diffraction rather than a reflection. Faults are drawn with dashed lines; they are shown only where they are required by offset beds. When fault dip is indeterminate, faults are drawn vertically. Seismic horizons corresponding with Pliocene/Miocene, upper/middle Miocene, and middle/ lower Miocene boundaries at Sites 438 and 439 are indicated by coded lines. Shotpoints (SP) on the horizontal scale are spaced 50 meters apart.) 


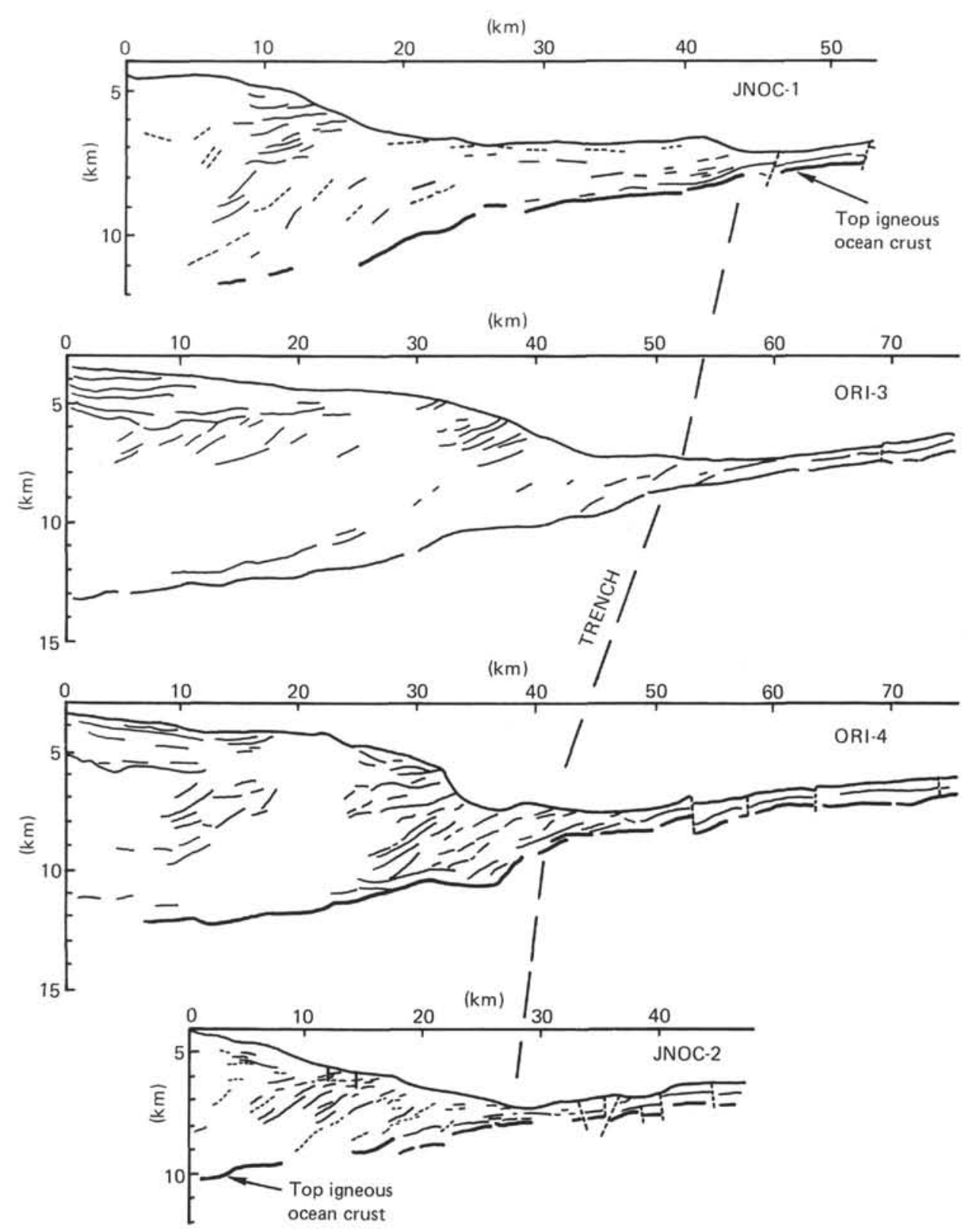

Figure 3. Sketched depth sections of multichannel seismic records across the lower slope. The depths and dips of reflection below $8 \mathrm{~km}$ are relatively unknown. (Derived from tracings in Figure $2 B$ and from ORI records in Nasu and others, 1979. The velocities used to convert time to depth in JNOC-1 and JNOC-2 are derived from the data in Figure 4 and from the seismic refracton data of Murauchi and Ludwig [this volume]. The vertical scale equals twice the horizontal scale.)

has been called a "deep sea terrace." The physiography and geology of the terrace are essentially that of a continental shelf, with slopes generally less than $1^{\circ}$. In this volume, deep sea terrace is used for the shelflike area (Figure 5) and trench slope for the area of steeper sea floor dips between the deep sea terrace and the trench (dips greater than $1^{\circ}$ and generally $3^{\circ}$ to $4^{\circ}$ ).

The seismic reflection records show geology and structure of a continental character beneath the deep sea terrace and trench upper slope, an oceanic character beneath the deep ocean seaward of the trench axis, and a character intermediate between continental and oceanic beneath the trench lower slope. These domains of structural character will be described in that order.

\section{Continental Crust}

A distinct feature of the continental part of the records is the angular unconformity that separates landward-dipping, faint reflections below from coherent, near-horizontal reflections above the unconformity. The unconformity is commonly characterized by many diffractions and less commonly by short, straight, high- 


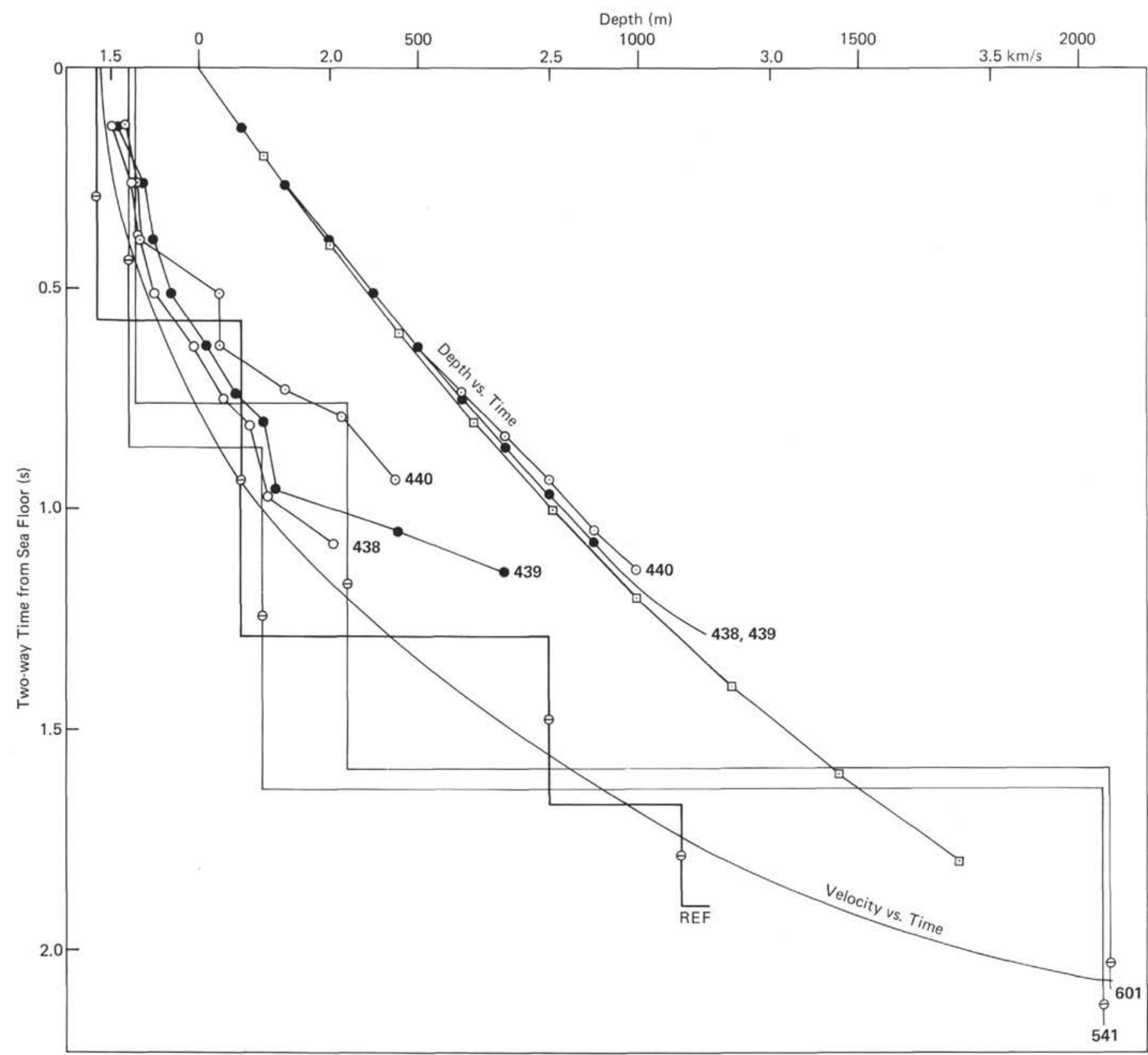

Figure 4. Velocities measured in the upper 2000 meters of sediment along the landward side of the Japan Trench Transect (from Saki et al., this volume). (The vertical scale equals 4 times the horizontal scale at sea floor.)

amplitude, low-frequency reflections. The unconformity is one to two seconds below the ocean floor and extends from the western edge of the JNOC records seaward almost to the trench midslope terrace. The highly diffractive unconformity becomes gradually less distinct seaward toward the midslope terrace as water depth increases. The decrease in resolution may be caused in part by increasing depth and by an increasing angular concordance in the attitude of reflections above and below the unconformity, but it may also result from an increase in deformation of the trench lower slope.

Reflections below the unconformity are moderately coherent, faint, commonly straight, of low frequency, and dip $20^{\circ}$ to $30^{\circ}$ landward in the time sections. The dip of these reflections tends to decrease near the trench midslope terrace (Figures 2 and 3). Above the unconformity, the reflective sequence is more coherent and generally dips less than $5^{\circ}$. The coherency of reflections decreases with the increasing depth of the trench slope.

In JNOC Record 1, a broad high at the west end of the record corresponds to Hachinohe Knoll (Figure 1), along whose east flank reflections lap down against the unconformity. The thickness of successively higher reflection pockets above the unconformity increases seaward, indicating a seaward migration of the depocenter up to a position on the slope where subsurface reflections crop out. Faults are indicated by termination or deflection of reflections and by diffractions. The successively greater offset of some deeper reflections suggests synsedimentary faulting. 


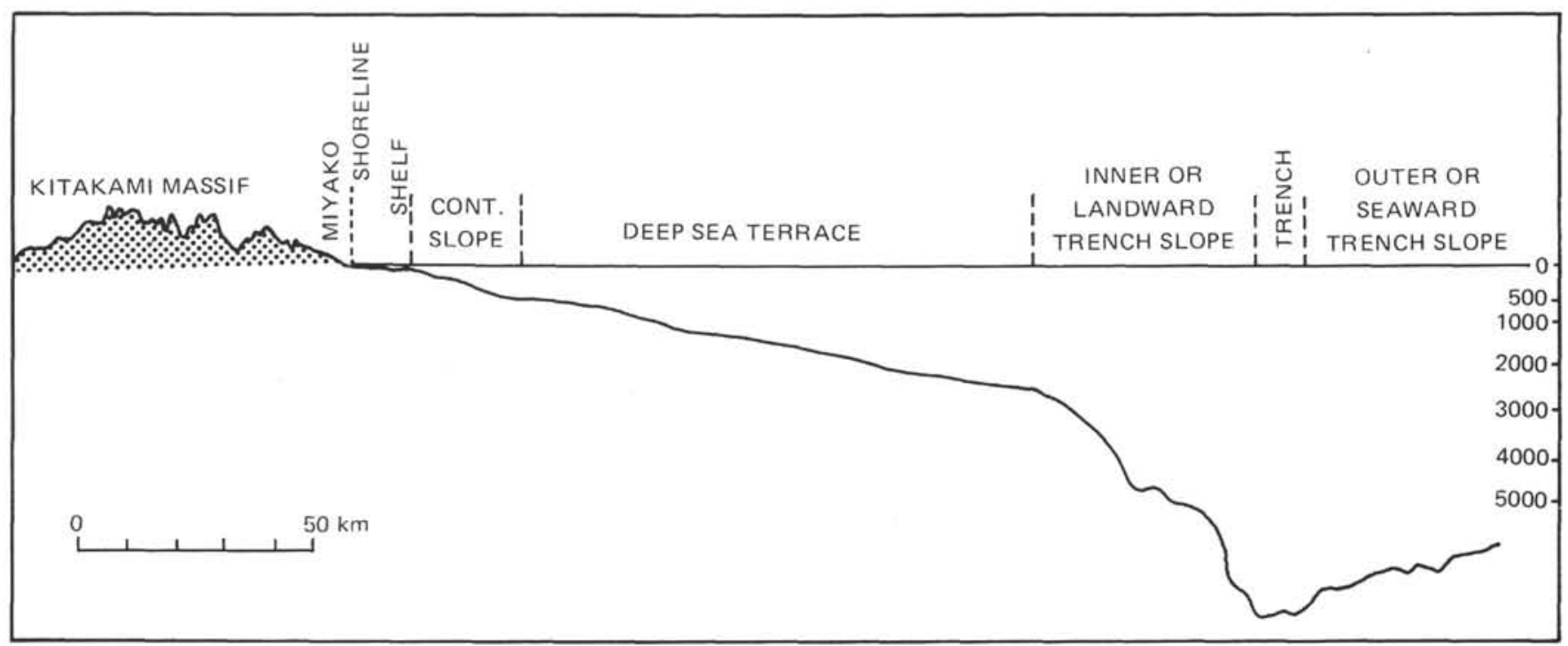

Figure 5. Physiographic nomenclature used in Volumes 56, 57, Parts 1 and 2.

In JNOC Record 2, reflections clearly crop out and are truncated on the trench slope. A notable feature in JNOC Record 2 is the filled trough, which is seen more clearly in the multichannel and on some single-channel seismic reflection records. Beneath the trough, there are a series of reflections in the multichannel record that pinch out against either flank (Figure 6). The strata of late Miocene age have a depocenter landward of the trough. Strata of Pliocene age beneath the trough are not thin and their depocenter is seaward of the trough. The latest strata filling the trough that cannot be traced to Sites 438,439 , and 435 are thus identified as only late Pliocene or younger. In contrast to strata underlying the trough, in which the depocenter migrated seaward as the deep sea terrace subsided, those filling the trough have a landward-migrating depocenter indicating uplift along the seaward bank of the trough (Figure 6). This history of pre-Pliocene subsidence followed by Pliocene and younger uplift is also substantiated by benthic foraminifers from Sites 439 (Keller, this volume; Arthur et al., this volume) and 435 (Thompson, this volume).

The trough can be traced north in the single-channel seismic data (Figure 7, Honza, this volume), although it is not as distinct in some records as in JNOC 2. JNOC A parallels the trough to about JNOC 1 and also shows the sediment filling it. Perhaps there is a break in the trough at about Record 20, but the data are not complete enough to fully establish continuity and disruption in the Record 20 area.

The horizons dated paleontologically at Sites 438 and 439 were correlated with seismic horizons through synthetic seismograms (Saki et al., this volume) and then traced along seismic reflection horizons. The Miocene/Pliocene boundary horizon is readily followed under the deep sea terrace but is increasingly difficult to trace as depth below the trench slope increases. Successively deep horizons were followed with increasing difficulty. It became necessary to make jump correlations based on seismic character; these are shown with dashed lines. The horizons were also followed on the record of Beck and others (1976).

\section{Oceanic Crust}

Short segments of the ocean basin section seaward of the trench are contained in the JNOC and ORI records (back pocket, this volume, $\mathrm{Pt}$. 1). Reflections in the upper $0.4 \mathrm{~s}$ are characteristic of sediment. Below $0.4 \mathrm{~s}$, reflections are characteristic of the top of igneous ocean crust. At about 1.6 to $1.8 \mathrm{~s}$, occasional straight, lowfrequency reflections occur that are presumed to come from the Moho. Matsuzawa and others (in press), through further processing of the records, have enhanced these features and show that they are consistent with the Moho reported in refraction studies.

Normal faults on the trench seaward slope such as those reported by Ludwig and others (1966) are visible between Shot points (SP) 2400 and 2450 , JNOC Record 1 (back pocket). Such faulting is displayed even more clearly in the ORI postcruise seismic records (Nasu et al., 1979) and on single-channel lines (Honza et al., 1977; Ludwig et al., 1966).

The reflections from the top of the igneous ocean crust can be followed under almost the entire trench landward slope in the multichannel reflection records. The reflection horizon consists of broad defracted reflections of low frequency. This same configuration was noted by Matsuzawa and others (1980).

\section{The Trench Lower Slope}

The seismic records across the trench lower slope are less clear than elsewhere, and structure differs from record to record. JNOC Record 1 has a $30-\mathrm{km}$-long, nearly flat, extended lower slope toe in front of a steep $\left(5^{\circ}\right)$ slope. Diffractions from the sea floor almost completely mask internal structure in the toe; however, the migrated time section presented by Matsuzawa and others (in press) has clear indications of horizontal reflections immediately above basement, some of which are faintly 


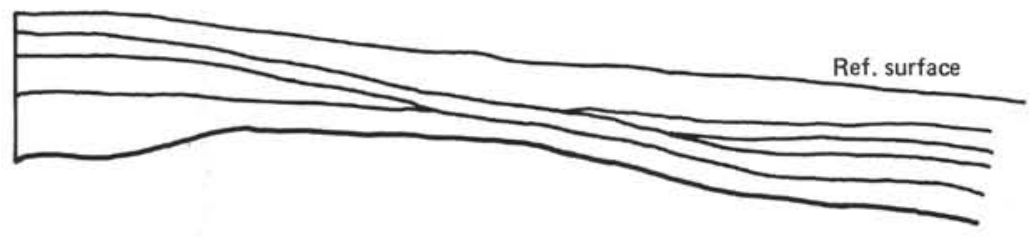

A

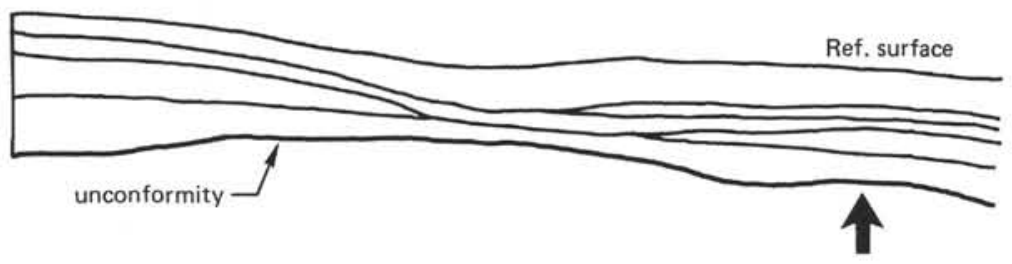

B
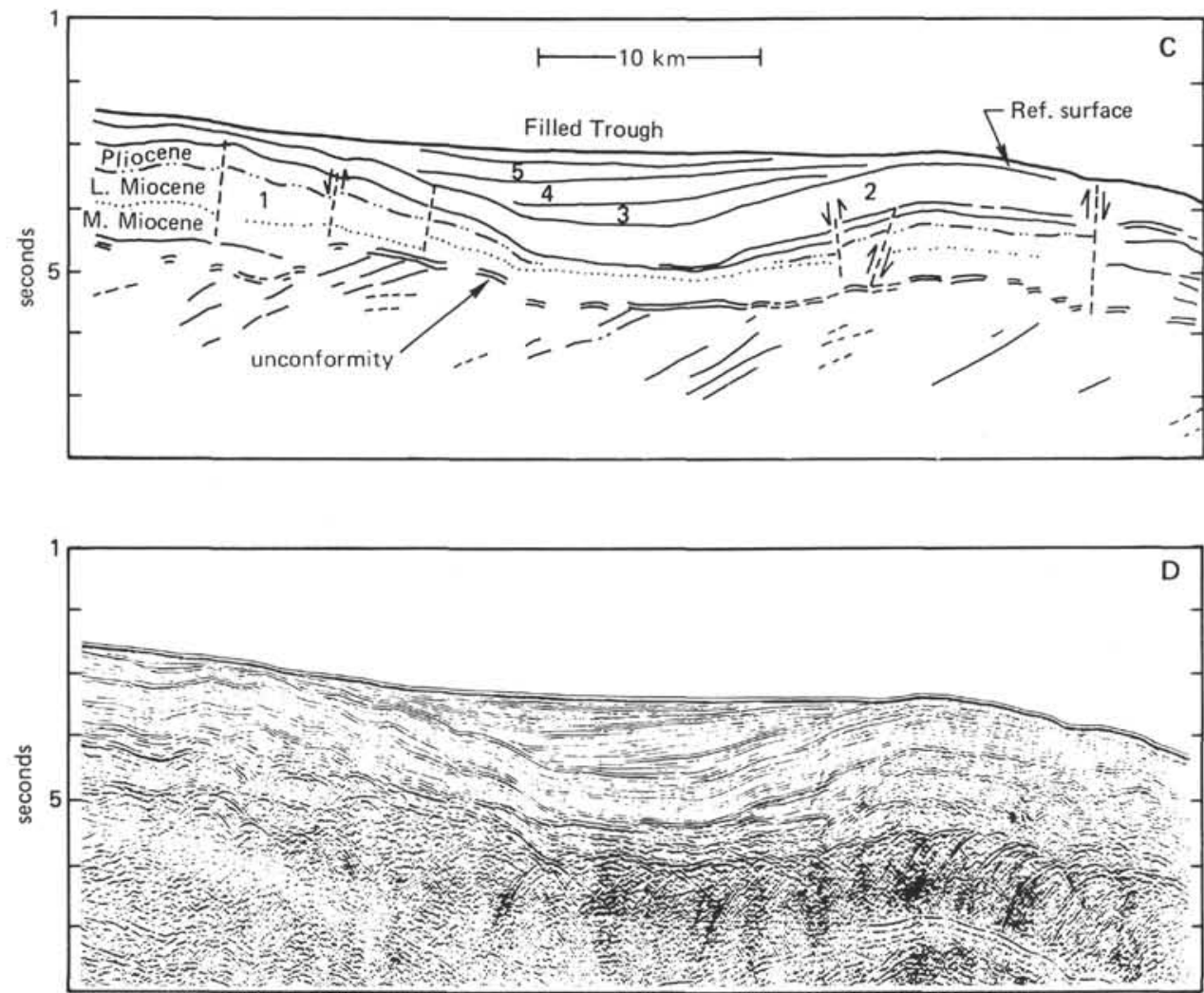

JNOC 2

Figure 6. Part of JNOC Record 2, showing the filled trough (D). (Numbers in line drawing of the record $[\mathrm{C}]$ indicate the successive depocenters and show how the late Miocene depocenter [1] migrated seaward in the Pliocene [2] and how the depocenters then reversed their direction of migration and shifted landward in response to uplift of the outer margin [3-5]. Sketches $A$ and B indicate a history of the development of the trough. The reference surface for construction of the sketches is indicated in $A, B$, and $C$. Sketch $A$ indicates possible structure during deposition of the lower Pliocene. Sketch B indicates structure as uplift of the seaward bank began.)

visible in the unmigrated data (back pocket and Figure 2 ). Under the steep part of the slope, most reflections have a low landward dip, and it is difficult to distinguish diffractions from reflections.
JNOC Record 2 has only a steep lower slope, but no toe. At the base of the slope, subhorizontal reflections are rotated back as they dip landward. Farther up the slope is a sequence of reflections with a seaward dip 


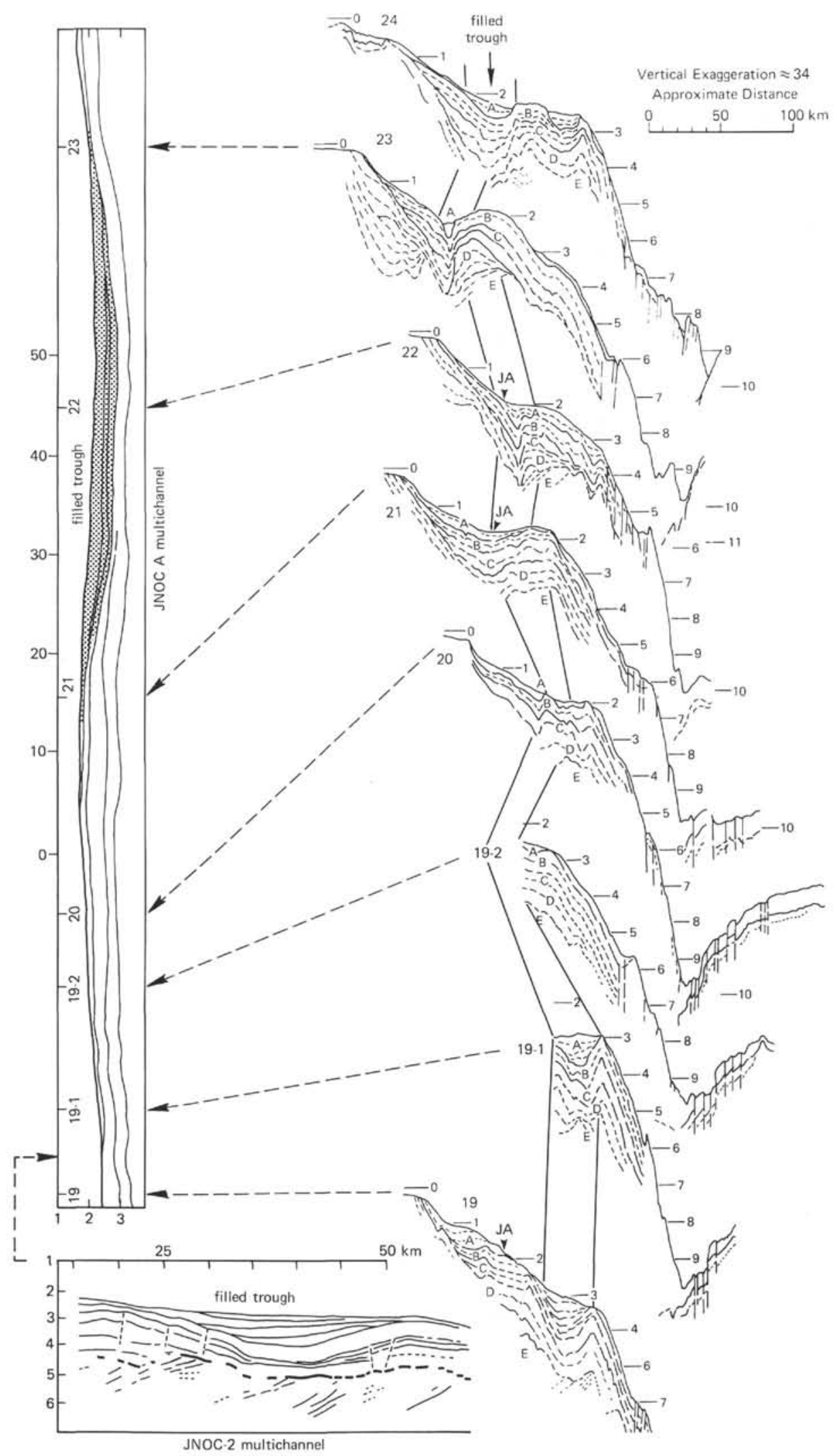

Figure 7. Location of the filled trough shown in Figure 5 under the deep sea terrace as seen in a series of single-channel seismic reflection records described by Honza (this volume) and in JNOC Record A. (JA indicates intersection of $J N O C$ - $A$ on the single-channel records. Vertical axis on all records in seconds.) 
(about SP 1800 to SP 2000) that cover the landward-dipping reflections. Between JNOC 1 and 2 are the ORI records, which show the toe seen in JNOC Record 1, but it is only $11 \mathrm{~km}$ long in Record 3 and $7 \mathrm{~km}$ long in Record 4. Single-channel records indicate that the toe is present only in the northern part of the transect area (Honza et al., 1977). Under the steep part of the trench lower slope, the ORI records show an exceptionally thick, orderly reflective sequence with near-horizontal strata.

\section{INTERPRETATION OF SEISMIC RECORDS}

Interpretation of the seismic records is significantly constrained by the results of drilling that have been reported in preliminary papers (Langseth, Okada et al., 1978; von Huene, Nasu et al., 1978) and in the chapters in this volume. The single most important regional tectonic event is subsidence of the Oyashio landmass during the Neogene. At Sites 438 and 439 the Oyashio landmass has subsided roughly $3 \mathrm{~km}$ since the early Miocene (Keller, this volume; Arthur et al., this volume). Results from study of the drill cores are referred to as they pertain to the interpretations that follow. As in the previous section, we deal first with the continental area, then the oceanic area, and finally the trench lower slope.

One feature in the reflection records that contributes to the continental character of the area with a continental velocity structure (Murauchi and Ludwig, this volume) is the unconformity. The apparent dip of sediment below the unconformity is between $8^{\circ}$ and $25^{\circ}$, averaging about $18^{\circ}$ (Figure 3). Dips as great as $70^{\circ}$ were observed in Sample 439-38-1, but because the maximum dip resolvable in the seismic records in approximately $30^{\circ}$, the records are biased toward low dips. Nonetheless, assuming an $18^{\circ}$ true dip, the beds below the unconformity should be more than $30 \mathrm{~km}$ thick. Therefore some tectonic repetition of beds, or perhaps isoclinal folding, might be inferred from this unusual thickness and from the variations in apparent dip.

A subsidence history of the Oyashio ancient landmass can be derived by noting the termination of beds of known age against the unconformity. If the entire angular unconformity is a subaerial erosion surface, as was established at Site 439 , then a marine transgression over the last subsiding remnant of the Oyashio landmass should be recorded by the transgression of sediment (Figure 8).

Above the unconformity, particularly in the western part of JNOC Record 1, onlap indicates seaward transgression to about SP 1150 (see seismic records, back pocket). Beyond SP 1150, the detail along the unconformity becomes obscure, but the Neogene section parallels the unconformity, indicating rapid or complete submergence of the landmass. In the western part of JNOC Record 2, the onlap also indicates seaward transgression to the area of the channel (SP 700). Seaward of the channel, however, the attitude of beds suggests a slight landward transgression. A landward and seaward transgression can be defined in the seismic records of Beck and others (1976) at corresponding positions.

The last subaerial remnant of the Oyashio landmass appears to have been at the top of the present trench up-

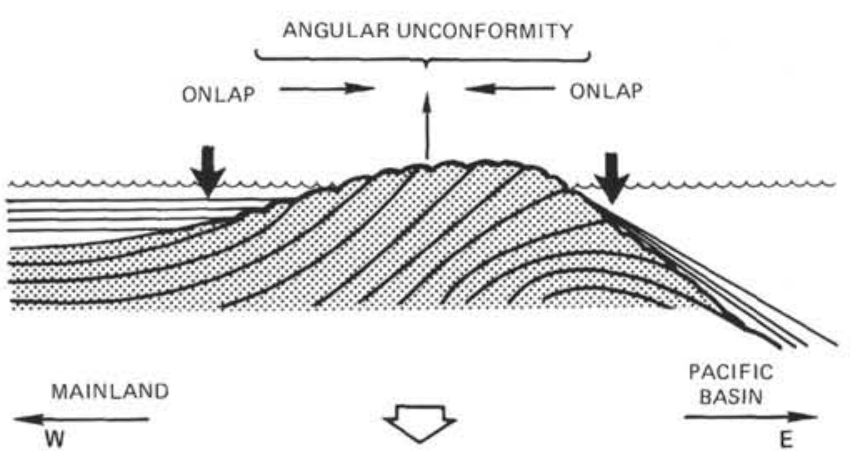

Figure 8. Diagram showing the inferred sequence of transgression across the erosional unconformity on the Oyashio landmass as it subsided.

per slope (JNOC Record 1, SP 1100; JNOC Record 2, SP $1100-1200$ ) and is covered by late Miocene beds.

The subaerial extent of the Oyashio landmass is indicated by the extent of the unconformity. The seaward extent of the unconformity is indeterminate, because the unconformity becomes increasingly obscure as it plunges deeper and fades away at its seaward end. In JNOC Record 1 the unconformity appears to extend at least to the midslope terrace (SP 1900), beyond which most reflections become discontinuous. In JNOC Record 2 the unconformity can also be traced to the midslope, but at approximately that point the reflections below the unconformity become nearly conformable with those above it. In Records 3 and 4 the unconformity fades out at the midslope terrace, and its seaward extent is indeterminate. In the record of Beck and others (1976) the angular discordance across the unconformity appears to diminish just upslope from the trench midslope terrace. The seaward extent of the unconformity is at least the midslope terrace, and it may once have extended even farther seaward. Thus it is possible that in the Neogene the seaward extent of the Oyashio landmass was at the present trench midslope terrace.

The landward end of the angular unconformity is at the western ends of JNOC Records 1 and 2. Ishiwada and Ogawa (1976) and Ishiwada and others (1977) indicate Paleogene sediment just landward of JNOC Record 2 . Thus the duration of the hiatus probably decreases, at least locally, as the unconformity is followed landward, and the hiatus of latest Oligocene to Cretaceous time at Site 439 may be represented by a lesser hiatus farther landward. JNOC Record 1 may indicate late Paleogene strata at the western end of the record, but this inference is based on the rapid increase in thickness of sediment beneath the mid-Miocene reflection rather than on dated seismic reflectors.

In general, faults in the continental part of the records have vertical displacements of less than 100 meters and are not large enough significantly to displace the unconformity. More important, these faults are normal rather than reverse, as is usually postulated for convergent margins. In JNOC Record 1 normal faults with less than 100-meter displacement are numerous on the seaward flank of Hachinohe Knoll. These faults could have been formed by uplift of the knoll during much of 
the Neogene. Farther seaward, where the fault planes are established with less certainty, some of the faults could be reverse.

In JNOC Record 2, landward of the filled trough, the gentle folds have a vergence and displacement suggesting slight extension. Seaward of the channel there appeárs to be no well-established pattern in the type of faulting. However, the attitude of bedding in some blocks (SP 1300-1400) suggests back rotation as though there were large slump blocks present. Considering the positions of the Miocene/Pliocene boundary and the apparent attitude of bedding present there is obviously much unresolved structure in the reflection records between Sites 435 and 440 . The Miocene/Pliocene boundary at Site 440 is far below the position projected from Site 435 on the basis of age and the structure visible in seismic records; therefore we infer a large vertical displacement occurring between the two sites. Since there is no apparent displacement of the strong, deep reflectors between the sites, tectonic activity may have included a low-angle thrust fault or massive slumping of a large block, as well as downbowing.

The structural interpretation that seems most consistent with our data involves downbowing of the seaward edge of the continent during the subsidence of the Oyashio landmass. The unconformity has subsided 2 to $3 \mathrm{~km}$ beneath the deep sea terrace and up to $6 \mathrm{~km}$ beneath the trench slope (Figures 2 and 3 ). This bending is similar to the bending of the ocean crust seaward of the trench, which has been the explanation for development of the steep faults on the trench seaward slope (Ludwig et al., 1966; Honza et al., 1978).

The oceanic section is recorded in short multichannel record segments across the trench seaward slope. The section has a prominent reflection at about mid-depth, and the igneous ocean crust is not as pronounced a reflective horizon. This is explained by the section drilled at Site 436 . At Site 436 the upper 340 meters are upper middle Miocene to Quaternary hemipelagic sediments of low velocity that grade downward through a 20-meter-thick deep ocean pelagic section into Cretaceous sediment containing chert. Although the acoustic impedance contrast is large between the Cretaceous chert and Tertiary sediment, it is probably not as large between the chert and altered ocean basalt. In the singlechannel record across this site (Nasu and Kobayashi, in press), the Neogene section corresponds to a sequence of low-amplitude reflections. Beneath, the Cretaceous beds exhibit high-amplitude, low-frequency reflections. The basement reflection has an amplitude and frequency similar to the Cretaceous reflectors.

The single-channel record made by Nasu and Kobayashi (in press) across Site 436 joins the seaward end of JNOC Record 2. At Site 436 the Neogene section is above, and the Cretaceous below, the prominent midsection reflection in JNOC Record 2. The basement has the same characteristic lack of definition. The more uniform reflective character in the multichannel records relative to the single-channel record, may be a result of gain control in the record-processing. The other multichannel records show a more distinct amplitude difference between the upper and lower parts of the section and the same change in the character of reflectance as the single-channel record across Site 436.

In JNOC Record 1, the prominent reflection corresponding to the Neogene/Cretaceous boundary can be traced beneath the trench seaward slope and for at least $10 \mathrm{~km}$ beneath the toe of the trench landward slope. The prominent reflection may continue farther as part of the apparent reverberant reflective sequence marking the top of the igneous ocean crust. Thus the Cretaceous oceanic section extends without major tectonic disruption for at least $10 \mathrm{~km}$ beneath the trench landward slope, and perhaps farther.

Steep faults break the oceanic crust where it bends down to form the trench, as was first pointed out by Ludwig and others (1966). The single-channel seismic records, with high vertical exaggeration illustrate faulting of the trench seaward slope more convincingly than the multichannel records with lower vertical exaggerations. The faults visible in the multichannel records are certainly steep, but in one or two instances the dip of the fault planes could be interpreted as on either side of vertical. In migrated presentation of Records 3 and 4 (Nasu et al., 1979), the interpretation of the fault planes is less ambiguous, and all but one fault appears to be reverse (Figures 2 and 3 ).

The trench lower slope velocity structure is intermediate between continental and oceanic (Murauchi and Ludwig, this volume). The trench lower slope is often presumed to be an area of subduction-related tectonic accretion. In JNOC Record 2 such an interpretation has been made (von Huene et al., 1978) as will be discussed later. However, in JNOC Record 1 the configuration of the toe of the trench slope is peculiar, because the toe fills the trench and offsets its axes (Figure 9), the top of the toe is a nearly level surface rough enough to produce many diffractions, and there is probably some near-horizontal layering as well as a few landward-dipping reflections in Lines 3 and 4 (Figure 3). These observations are more consistent with origin by mass movement and subsequent deformation by convergence than with one by subduction and accretion.

From the trench to the midslope terrace, the JNOC Record 1 contains only disjointed reflections to indicate deeper structure. There are short, coherent near-horizontal reflections that are perhaps short, coherent segments of a tectonically jostled terrain. The ORI records show a very thick sequence of more coherent nearhorizontal reflections beneath the trench lower slope. There are few constraints on the interpretations of the lower slope in these records, and the tectonically jostled section could just as well be a subsided continental fragment as a subduction accretion sequence. However, it is interesting to note that the nearly horizontal beds appear to crop out on the trench lower slope as if they had been truncated at the sea floor. Slope deposits generally thin and punch out downslope rather than ending abruptly. This structural configuration suggests continued slumping or some other mechanism whereby beds are not deposited on the steep trench lower slope.

The trench lower slope depicted in JNOC Record 2 has an upper sequence in which the beds are subparallel to the slope and dip seaward and a lower sequence in 

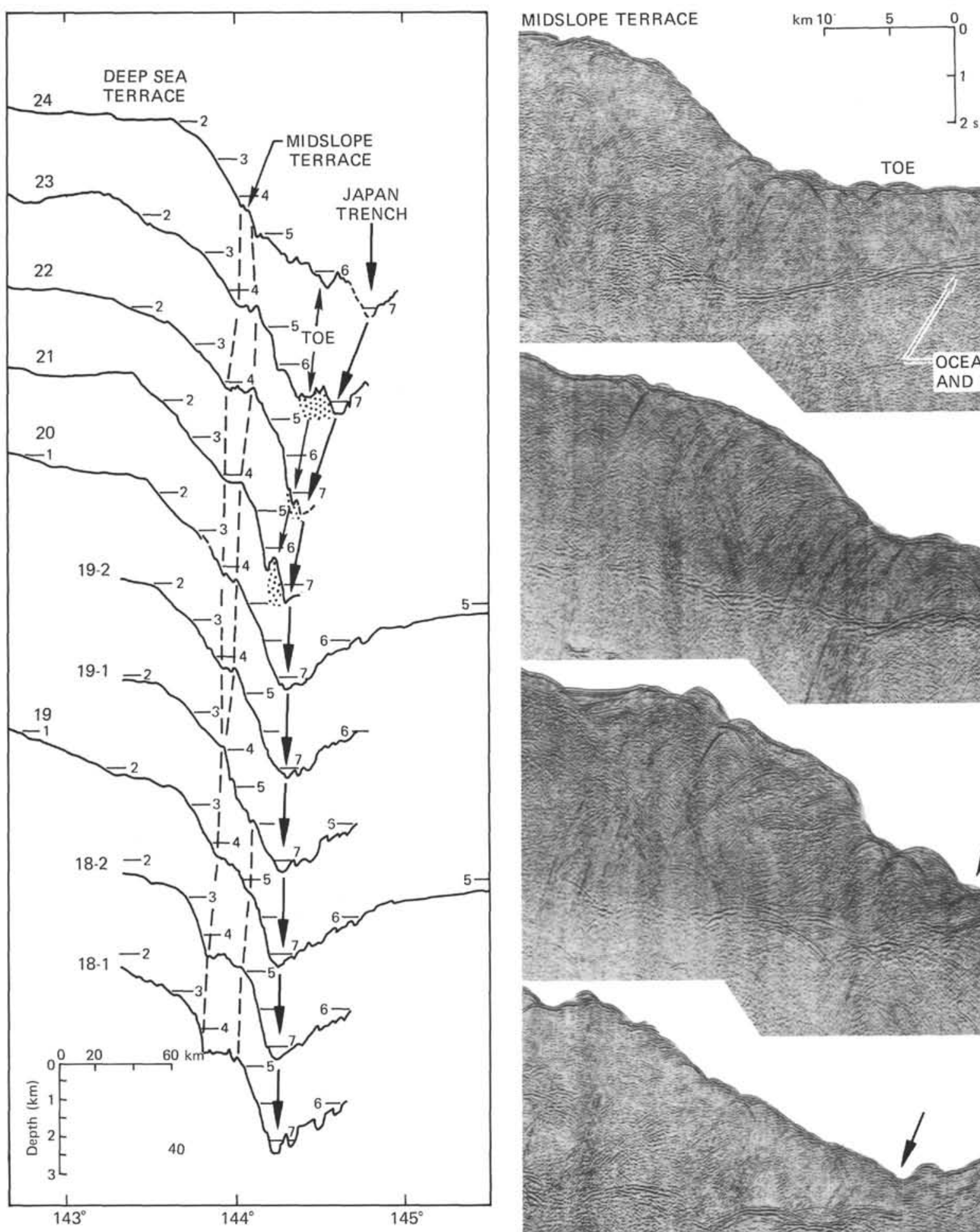

A
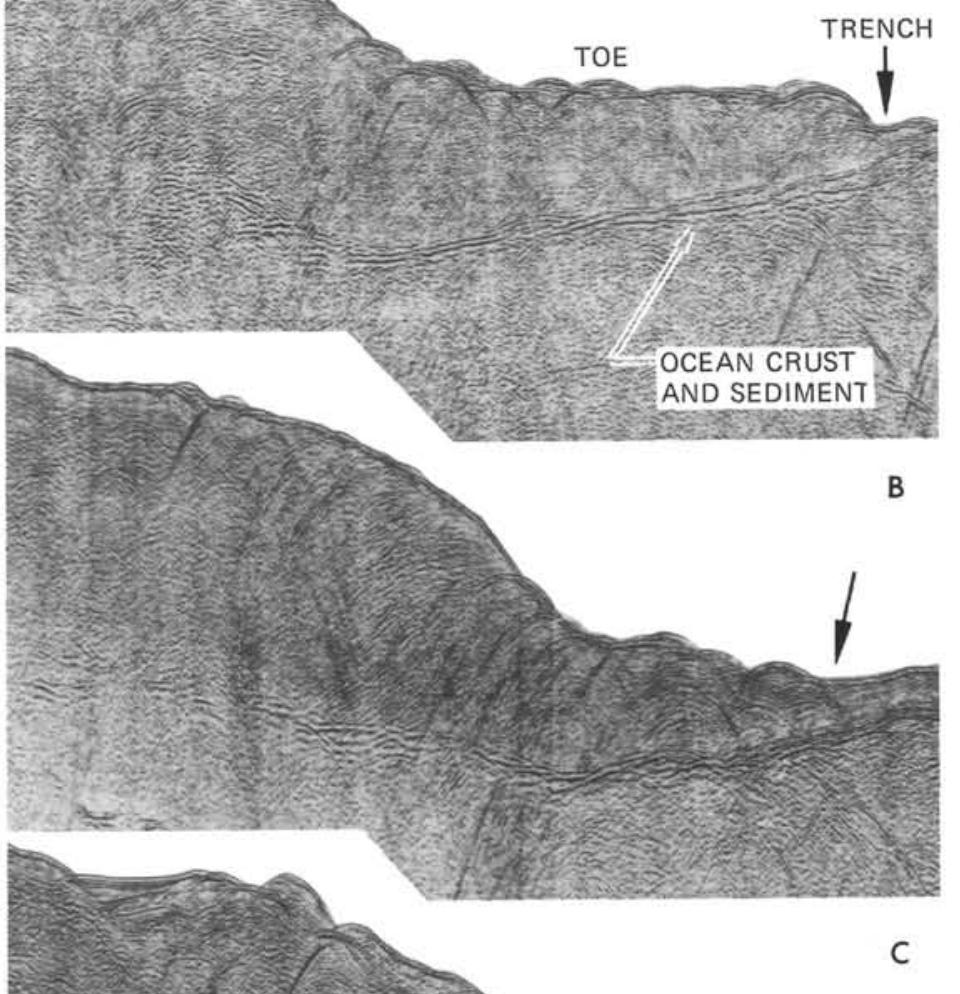
which they dip landward. These sequences appear to be separated by a faint horizontal boundary (Figure 3 ). Most of the drilling at Sites 434 and 441 was in the upper sequence, where we encountered a hemipelagic slope section in a normal stratigraphic succession to late Miocene. One repeated age sequence, which may have been caused by slumping or tectonism, was recovered at the bottom of Hole 434. Perhaps Hole 434 penetrated the top of the lower sequence. The upper sequence appears to consist mainly of hemipelagic deposits. The lower sequence is essentially undrilled; thus the interpretation is based only on geophysical evidence. The landward dip in the lower sequence increases from the trench landward, showing the commonly inferred geometry of an accretionary prism. The landward-dipping sequences of JNOC Records 1 and 2 are interpreted as material accreted during subduction, and this interpretation is not exclusive. Based on the lithologies recovered at Sites 434 and 441 and on the dips that are in an opposite direction to those of accretionary models (Seely, 1977; Dickinson and Seely, 1979), the overlying sequence that dips seaward is interpreted as having been deposited on the slope.

There appears to be a profound change in structure of the trench slope at the midslope terrace according to both the seismic reflection records and the refraction data (Murauchi and Ludwig, this volume). Very little information about the kinematics of this boundary is disclosed by the existing seismic records.

\section{CONCLUSIONS}

Interpretation of the multichannel records in the Japan Trench Transect is constrained by the drill core data and by previous geophysical surveys. There appears to be a fundamental juncture between continental and ocean crust, in an area where the structure is not clearly resolved. The continental crust extends to the trench midslope terrace. The igneous ocean crust extends landward of the trench and can be traced under the continental crust. The downbowed ancient subaerial surface along the angular unconformity indicates that the seaward edge of the continental crust subsided. The downbowing also explains the series of steep faults beneath the trench upper slope. Because the vertical displacement on these faults cannot be resolved by seismic methods, we cannot identify the initiation of faulting. The compressional stress from convergence of the oceanic and continental plates appears to have been communicated only to the very frontal part of the upper plate, off northern Honshu. Large-scale slumps or other forms of gravitational failure are suggested by back-rotation of some beds and displacement of age horizons between drill holes on the slope; however, here too the definition of structure is insufficient to infer slip planes with much confidence. Near its juncture with the Kurile Trench, the Japan Trench appears to be filled with a large accumulation of material from downslope mass movement. This material forms the toe of the slope observed in JNOC Record 1. The zone of subduction-accreted material is limited to small areas beneath the trench lower slope. The zone is covered by seaward-dip- ping horizons from which slope deposits were recovered by drilling.

The tectonic history of the seaward edge of the Japan margin off northern Honshu, interpreted from the geophysical and geological data, involves accumulation of Cretaceous deposits, landward-tilting, and perhaps repetition of section by tectonism between the Late Cretaceous and the late Paleogene, as well as subsequent or coincident uplift and emergence of at least the seaward part of the continent. The upturned Cretaceous section was intruded by calc-alkaline magmas, eroded, and began to submerge relative to sea level with deposition of a transgressive sequence of beds in the late Paleogene or earliest Neogene. By the late Miocene most of the landmass was at sea level, and since that time it has subsided some 3 to $6 \mathrm{~km}$. The seaward edge of the landmass was bowed down during subsidence, and a sedimentary section was added seaward of this edge as part of the subduction process. Subduction accretion has occurred since at least deposition of the upper Miocene slope sediment above the accreted prism, but the accreted subduction complex is confined to a small area beneath the trench lower slope. This also supports the observation compressional stress affects only the frontal part of the upper plate off northern Honshu.

\section{ACKNOWLEDGMENTS}

We extend our sincere gratitude to the many scientists and technicians who were involved in collecting data aboard the Kaiyomaru and processing it. Their work resulted in the multichannel seismic reflection records shown in this volume. The list is too long to mention all of them by name. We are deeply grateful for release of the records by the Japan National Oil Corporation (formerly Japan Petroleum Development Corporation) and appreciate particularly the persistent efforts of Dr. Arika Matsuzawa and Akira Kujiroaka. Furthermore, we extend our gratitude to Dr. Toshiro Tamano and his colleagues of the Japan Petroleum Exploration Company, who collected and processed the seismic data off Sanriku.

\section{REFERENCES}

Beck, R. H., Lehner, P., Diebold, P., Bakker, G., and Dout, H., 1976. New geophysical data on key problems of global tectonics. Proceedings of the Ninth World Petroleum Congress, 2, 3-32.

Dickinson, W. R., and Seely, D. R., 1979. Structure and stratigraphy of forearc regions. Am. Assoc. Petrol. Geol., 63, 2-31.

Honza, E., 1976. Tectonic development of the Tohoku Arc since the Neogene. In Nasu, N. (Ed.), Kaiyo Chishitsu (Marine Geology): Tokyo (Tokyo University Press), pp. 137-154. (in Japanese)

(Ed.), 1977. Geological investigation of Japan and southern Kurile Trench and slope areas, GH-76-2 Cruise. Geol. Surv. Jpn., Cruise Rept., 7, 1-127.

Honza, E., Kagami, H., and Nasu, N., 1977. Neogene geological history of the Tohoku Island arc system. J. Oceanog. Soc. Jpn., 33 (No. 6), 297-310.

Honza, E., Tamaki, K., and Murakami, F., 1978. Geological map of the Japan and Kurile Trenches and adjacent areas: Marine geological map series 11: Tokyo (Geological Survey of Japan). 
Hoshino, M., Iwabuchi, Y., Aoki, H., 1970. Shinkai Chishitsugaku (Deep Sea Geology): Tokyo (Tokai University Press), pp. 84-107. (in Japanese)

Iijima and Kagami, 1961. Cainozoic tectonic development of the continental slope, northeast of Japan. J. Geol. Soc. Jpn., 67, 561-577. (in Japanese with English abstract)

Ishiwada Y., Ikebe, Y., Ogawa, K., and Onitsuka, T., 1977. A consideration on the scheme of sedimentary basins of northwest Japan. Prof. Kazuo Huzioka Memorial Volume, pp. 1-7. (in Japanese with English abstract)

Ishiwada, Y., and Ogawa, K., 1976. Petroleum geology of offshore areas around the Japanese Islands. United Nations ESCAP, CCOP Tech. Bull., 10, 23-24.

Iwabuchi, Y., 1968. Topography of trenches east of Japan. J. Geol. Soc. Jpn., 74, 37-46. (in Japanese with English abstract)

Iwabuchi, Y., and Mogi, A., 1973. Summarization of submarine geology in each zone of Japanese upper mantle project. In Gorai, M., and Igi, S. (Eds.), The Crust and Upper Mantle of the Japanese Area: Tokyo (Japanese Commission for the Upper Mantle Project).

Langseth, M., Okada, H., et al., 1978. Near the Japan Trench transects begin. Geotimes, 23 (No. 3), 22-26.

Ludwig, W. J., Ewing, J. I., Ewing, M., Murauchi, S., Den, N., Asano, S., Hotta, H., Hayakawa, M., Asanuma, T., Ichikawa, K., and Noguchi, I., 1966. Sediments and structure of the Japan Trench. J. Geophys. Res., 71, 2121-2137.

Matsuzawa, A., Tamano, T., Aoki, Y., and Ikawa, T., 1977. Geotectonic structure beneath the Japan Trench off Sanriku. Seismol. Soc. Jpn., 2, 126. (preprint Abstract, in Japanese)

, 1980. Structure of the Japan Trench subduction zone, from multichannel seismic-refraction records. Mar. Geol., 35, 171-182.

Mogi, A., 1977. An Atlas of the Seafloor around Japan: Tokyo (Tokyo University Press). (in Japanese; English translation by Tokyo University Press, 1979)

Murauchi, S., Asanuma, T., Kinoshita, H., Nakatani, H., Mitamura, M., Sakai, M., Tokumaru, M., and Hayashi, K., 1979. Sediments and structure of subduction zone off northeast Japan. EOS, 60, 315.

Murauchi, S., Asanuma, T., Taguchi, H., Kinoshita, H., Yokoyama, I., Nakatani, H., Yokota, Y., and Tanaka, K., 1978. Crustal structure of the island-arc slope and the trench off Sanriku and mechanism of subduction. Kaiyokagaku (Marine Science), 10, 207-214. (in Japanese)

Nasu, N., 1961a. In Tsuboi, C. (Ed)., Submarine Bottom in Structure of the Earth: Tokyo (Iwanami), pp. 113-141. (in Japanese)

1961b. The provenance of coarse sediments recently discovered on the shelf and trench slopes off the Japanese
Pacific Coast. Tenth Pacific Science Congress, Abstract Papers, pp. 381-382.

1964. The provenance of the coarse sediments on the continental shelves and the trench slopes off the Japanese Pacific coast. In Miller, R. L. (Ed.), Papers in Marine Geology: New York (Macmillan), pp. 65-101.

Nasu, N., and Kobayashi, K. (Eds.), 1980. Preliminary results in the Japanese Deep Sea Expedition in 1959. Oceanogr. Mag., 11 (No. 2), 201-214.

Nasu, N., and Kobayashi, K. (Eds.), in press. Preliminary report of the Hakuho Maru Cruise KH-77-1 (IPOD Site Survey). Ocean Research Institute, University of Tokyo.

Nasu, N., and Sato, T., 1962. Geological results in the Japanese Deep Sea Expedition in 1961 (JEDS-4). Oceanogr. Mag. 13 (No. 2), 155-166.

Nasu, N., Tomoda, Y., Kobayashi, K., Kagami, H., Uyeda, S., Nagumo, S., Kushiro, I., Ojima, M., Nakazawa, K., Takayanagi, Y., Okada, H., Murauchi, S., Ishiwada, Y., and Ishii, Y., 1979. Multichannel seismic reflection data across the Japan Trench. IPOD-Japan Basic Data Series, No. 3, Ocean Research Institute, University of Tokyo, pp. $1-22$.

Ogawa, K., and Suyama, J., 1976. Distribution of aeromagnetic anomalies, Hokkaido, Japan and its geologic implication. In Aoki, H., and Iizuka, S. (Eds.), Volcanoes and Tectonosphere: Tokyo (Tokai University Press), pp. 207208.

Oshima, S., Kondo, T., Tsukamoto, T., and Onodera, K., 1975. Magnetic anomalies at sea around the northern part of Japan. Rep. Hydrogr. Res., 10, 39-44.

Sakurai, M., Nagao, M., Nagai, T., Katsura, T., Tozawa, M., and Ikeda, K., 1975. Submarine geology off the south coast of Hokkaido. Rept. Hydrographic Researches: Tokyo (Hydrographic Office of Japan), 10, 1-37.

Sato, T., 1973. Several considerations on the Deep Sea Plains. Kaiyokagaku (Marine Sciences), 5, 55-59. (in Japanese)

Seely, D. R., 1977. The significance of landward vergence and oblique structural trends on the trench inner slope. Maurice Ewing Series 1, Island Arcs, Deep Sea Trenches, and Backarc Basins: Washington (American Geophysical Union), pp. 187-198.

Tomoda, Y., 1973. Map of free air and bouguer gravity anomalies in and around Japan: Tokyo (Tokyo University Press).

Uyeda, S., 1974. Northwest Pacific Trench margins. In Burk, C. A., and Drake, C. L. (Eds.), The Geology of Continental Margins: New York (Springer-Verlag), pp. 473-491.

von Huene, R., Nasu, N., et al., 1978. On Leg 57 Japan Trench transected. Geotimes, 23 (No. 4), 16-21.

Yoshii, T., and Asano, S., 1972. Time-term analysis of explosion seismic data. J. Phys. Earth, 20, 47-58. 